Brit. F. vener. Dis. (1975) 51, 301

\title{
Effects of oxygen and nitrogen on the character of T. pallidum in subcutaneous chambers in mice
}

\author{
I. HORVATH, R. J. ARKO, AND J. C. BULLARD \\ From the Research Institute for Dermatology and Venereology, Budapest, Hungary, \\ and \\ the Venereal Disease Research Branch, Bacteriology Division, Bureau of Laboratories, Center for Disease Control, \\ Public Health Service, U.S. Department of Health, Education, and Welfare, Atlanta, Georgia 30333
}

Studies on the physiology of Treponema pallidum $(T p)$ have been limited by the inability of researchers to cultivate the organism in vitro. For many years microbiologists have considered virulent $T p$ to be anaerobic (Nelson and Steinman, 1948; Turner and Hollander, 1957); however, Cox and Barber (1974) advanced evidence to support the in vitro utilization of oxygen by $T p$ extracted from rabbit testicles. The investigators suggested that the previously observed inactivation of $T p$ by oxygen was due to the accumulation of oxidized metabolic products and not to the presence of oxygen. In this study we determined the effects of oxygen and nitrogen in subcutaneous chambers (Arko, 1973) in which the metabolic products from $T p$ would perhaps be buffered or removed by the tissue of the host animal. We also repeated the Cox and Barber (1974) method of preparing $T p$ extracts from rabbit testicles to assess the amount of rabbit tissue in these preparations as this tissue may have an important influence on any attempts to measure oxygen utilization by $T$. pallidum.

\section{Material and methods}

Subcutaneous chambers were prepared in adult, inbred, Institute of Cancer Research Mice (Arko, 1973) 6 to 11 days before $T p$ suspensions were injected. Virulent $T p$, Budapest strain (isolated by Kiraly, 1952), were used to infect rabbit testicles which were harvested (Turner and Hollander, 1957) 7 to 9 days later to prepare the $T p$ suspension for inoculating the mouse chambers. Each testicle was cut into thin slices and placed in $5 \mathrm{ml}$. of sterile normal saline. This suspension was then placed in a side-arm flask, and the atmosphere was exchanged three times with 95 per cent. $\mathrm{N}_{2}$ plus 5 per cent. $\mathrm{CO}_{2}$. After the third filling with $\mathrm{N}_{2}$ plus $\mathrm{CO}_{2}$, the suspension was vortexed for $30 \mathrm{~min}$. before it was centrifuged at $200 \mathrm{G}$. for $10 \mathrm{~min}$. The number of $T p$ used in each experiment was determined by darkfield examination of the supernate (Morgan and Vryonis, 1938). The supernate

Received for publication February 17, 1975

The research described in this report involved animals maintained in animal care facilities fully accredited by the American Association for Accreditation of Laboratory Animal Care. was adjusted with sterile saline so that the inoculum contained approximately $4 \times 10^{7} T p$ per $\mathrm{ml}$. Chambers within a group of mice of similar age, sex, weight, and implantation date were injected with $0.5 \mathrm{ml}$. of the $T p$ suspension by using a 25 -gauge needle. The inoculated mice were then randomly divided into three groups and treated in the following manner:

Group $\mathrm{O}_{2}$ received a $1-\mathrm{ml}$. intrachamber injection with oxygen;

Group $\mathrm{N}_{2}$ received a similar injection with $1 \mathrm{ml}$. nitrogen;

Group $\mathrm{K}$ received no treatment.

Three separate trials were made with the $\mathrm{O}_{2}, \mathrm{~N}_{2}$, and $\mathrm{K}$ treatment groups of mice. Fluid from the $T p$-inoculated chamber of each mouse was removed with a syringe and 25-gauge needle at approximately 24 -hr intervals and examined by darkfield microscopy. The number of $T p$ present in the fluid from each chamber and their relative motility were determined by counting 100 microscope fields at $\times \mathbf{4 5 0}$ magnification.

Other suspensions of $T p$-infected rabbit testicles were prepared for electron microscopy by the technique of Cox and Barber (1974). Testicular suspensions were centrifuged at $23,500 \mathrm{G}$. for $30 \mathrm{~min}$. in a refrigerated Sorvall RC-2B centrifuge. The sediment was fixed in $0.1 \mathrm{Mol}$ glutaraldehyde in cacodylate buffer, $\mathrm{pH} 7 \cdot 4$, for $90 \mathrm{~min}$. at room temperature, centrifuged at $23,500 \mathrm{G}$. for $30 \mathrm{~min}$., and washed in $0.1 \mathrm{Mol}$ cacodylate sucrose buffer rinse at $4^{\circ} \mathrm{C}$ overnight. The pellet was postfixed in 1 per cent. osmium tetroxide $\left(\mathrm{OsO}_{4}\right)$ in cacodylate buffer at room temperature for 90 min., dehydrated in graded ethyl alcohols, saturated with propylene oxide, infiltrated, and embedded in Maraglas 655. The specimen was sectioned with glass knives on a Servall Porter-Blum MT-1 ultramicrotome. The ultrathin sections were picked up on copper grids and stained with saturated uranyl acetate in methanol and lead citrate (Reynolds, 1963). They were examined first with a Philips 75 transmission electron microscope and then with a Philips 200 transmission electron microscope operating at $\mathbf{4 0}$ and $60 \mathrm{kV}$.

\section{Results}

The effects of $\mathrm{O}_{2}$ and $\mathrm{N}_{2}$ on the survival of $T p$ in vivo are given in the Table and graphically for Trial 3 in Fig. 1. The results from three trials with oxygen 
TABLE Average and median numbera of motile treponemes in mouse subcutaneous chambers at 24-hr intervals after oxygen or nitrogen treatment

\begin{tabular}{|c|c|c|c|c|c|c|c|c|c|c|c|}
\hline \multicolumn{3}{|l|}{$\frac{\text { Trial no. }}{\text { Hours }}$} & \multicolumn{3}{|l|}{$1^{b}$} & \multicolumn{2}{|l|}{$2^{c}$} & \multicolumn{4}{|l|}{$3^{d}$} \\
\hline Treatment & Oxygen & $\begin{array}{l}\text { Average } \\
\text { Median }\end{array}$ & $\begin{array}{l}24 \\
18.0 \\
16.0\end{array}$ & $\begin{array}{l}72 \\
0.4 \\
0.5\end{array}$ & $\begin{array}{l}120 \\
0 \cdot 2 \\
0 \cdot 2\end{array}$ & $\begin{array}{l}72 \\
3.6 \\
0.6\end{array}$ & $\begin{array}{l}120 \\
0 \cdot 12 \\
0.0\end{array}$ & $\begin{array}{l}24 \\
1.3 \\
1.0\end{array}$ & $\begin{array}{l}48 \\
0.2 \\
0.1\end{array}$ & $\begin{array}{l}72 \\
0 \cdot 1 \\
0 \cdot 1\end{array}$ & $\begin{array}{l}96 \\
0.03 \\
0.0\end{array}$ \\
\hline & Nitrogen & $\begin{array}{l}\text { Average } \\
\text { Median }\end{array}$ & $\begin{array}{l}56.6 \\
60.0\end{array}$ & $\begin{array}{l}5 \cdot 4 \\
5 \cdot 4\end{array}$ & $\begin{array}{l}0.2 \\
0.4\end{array}$ & $\begin{array}{l}5 \cdot 7 \\
2 \cdot 0\end{array}$ & $\begin{array}{l}2 \cdot 4 \\
2 \cdot 4\end{array}$ & $\begin{array}{l}59 \cdot 1 \\
50 \cdot 0\end{array}$ & $\begin{array}{l}25.0 \\
75.0\end{array}$ & $\begin{array}{l}0.26 \\
1.2\end{array}$ & $\begin{array}{l}0.6 \\
0.6\end{array}$ \\
\hline
\end{tabular}

a Number of treponemes determined by counting 100 microscope fields $(\times 450)$ and dividing by 10

b Three mice per group. Single $1 \mathrm{ml}$. gas injected $0 \mathrm{hrs}$ after injection of $0.5 \mathrm{ml}$. fluid containing $0.9 \times 10^{7}$ motile treponemes

- Five mice per group. $1 \mathrm{ml}$. gas injected 0 and $24 \mathrm{hrs}$ after injection with $3.5 \times 10^{7}$ motile treponemes

d Six mice per group. $1 \mathrm{ml}$. gas injected at 0 and $24 \mathrm{hrs}$ after injection with $1.9 \times 10^{7}$ motile treponemes

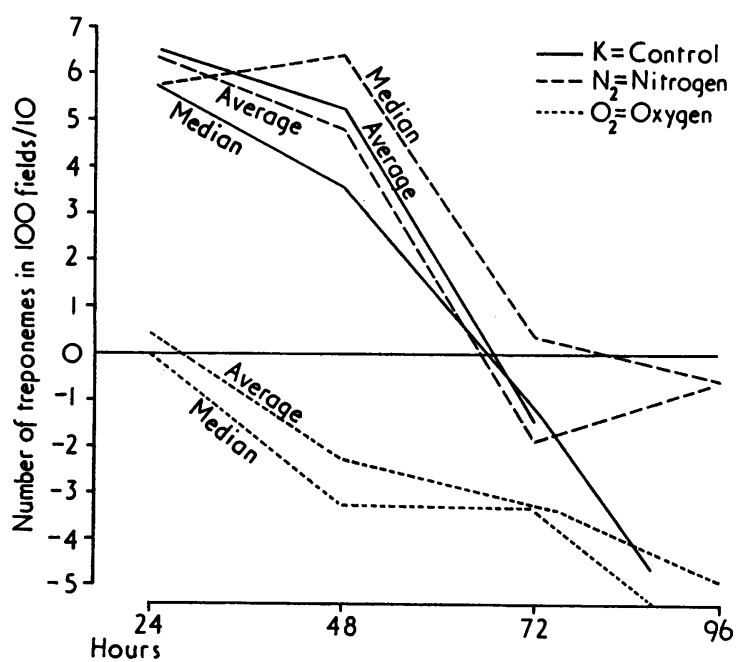

FIG. 1 Changes observed in number of motile treponemes in mouse subcutaneous chambers at 24-hr intervals after oxygen or nitrogen treatment

or nitrogen injected into subcutaneous chambers containing living treponemes reveal that the nitrogen environment was more suited for $T p$ survival; oxygen, on the other hand, appeared to exert a negative effect on survival. The greatest difference between the three treatment groups occurred in Trial 3. Subcutaneous chambers in these mice had been implanted for 11 days before inoculation with $T p$ and were more encapsulated with tissue than the 6-day chambers used in the other two trials (see Table). In Trials 2 and 3 the gases were injected at $0 \mathrm{hr}$ and again at $24 \mathrm{hrs}$ after inoculation with treponemes. In these trials the numbers of treponemes at 96 and $120 \mathrm{hrs}$ were much greater in the nitrogentreated group, which may reflect the increase in exposure to the action of the two gases.

The difference in the motility of $T p$ in the oxygenand nitrogen-treated group in all three trials was most noticeable in the observation made $24 \mathrm{hrs}$ after the gases were injected. At this observation a much larger number of nonmotile and sluggish $T p$ appeared in the oxygen-treated groups than in either the control or nitrogen groups. In all trials gas persisted in the oxygen chamber for a much shorter time than in the nitrogen-injected chamber, probably because the animal tissues absorbed more oxygen than nitrogen. The presence of gas did affect the collection of fluid samples from the mouse chamber; those with gas present tended to contain less fluid and required more time for sample collection. However, after $72 \mathrm{hrs}$, the chambers in all three groups had similar amounts of fluid.

The electron micrographs (Figs 2 to 5 ) of tissue suspensions prepared from $T p$-infected rabbit testicles by the Cox and Barber technique revealed the presence of intact red and white blood cells as well as other rabbit-derived tissue debris (as in Fig. 4). A greater amount of tissue components, especially red blood cells, were microscopically observed in suspensions prepared from infected testicles as compared to normal testicles.

\section{Discussion}

The injections of either oxygen or nitrogen into mouse chambers containing living $T p$ produced a demonstrable effect on the survival of the microorganism. Oxygen exerted a deleterious effect during the first $24 \mathrm{hrs}$ after injection; nitrogen, on the other hand, enhanced both the number of $T p$ and their survival time.

Specimens were prepared from $T p$-infected rabbit testicles by the method of Cox and Barber (1974) and were examined with an electron microscope. These $T p$ suspensions contained a significant amount of rabbit tissue. The presence of and inconsistency in amounts of these tissue components in $T p$ infected and noninfected testicular suspensions would appear to make accurate oxygen uptake determinations for $T p$ very difficult. On the other hand, in spite of the oxygen uptake by $T p$, it is difficult to imagine that the micro-organism is aerobic, because : 
2

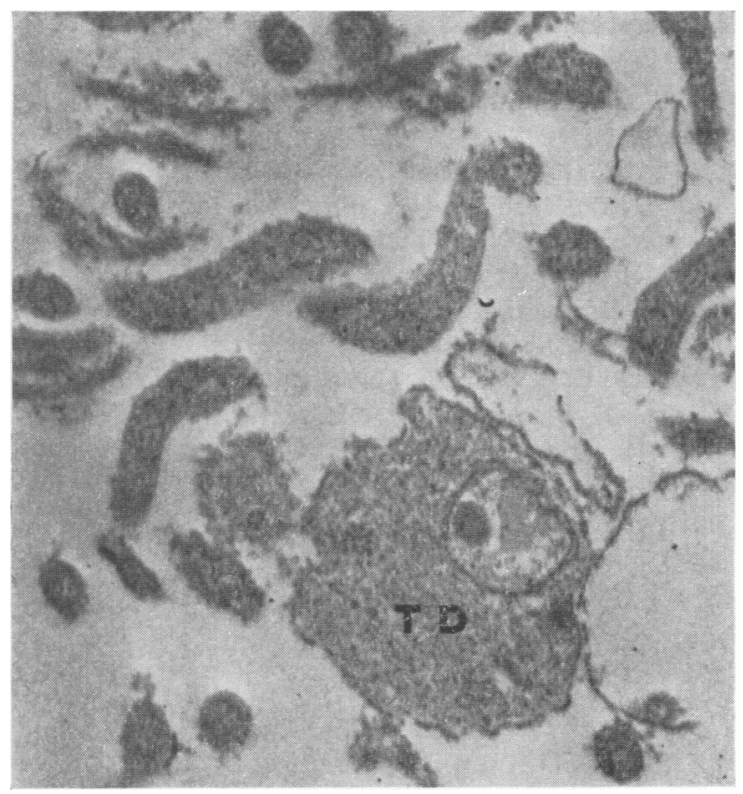

4

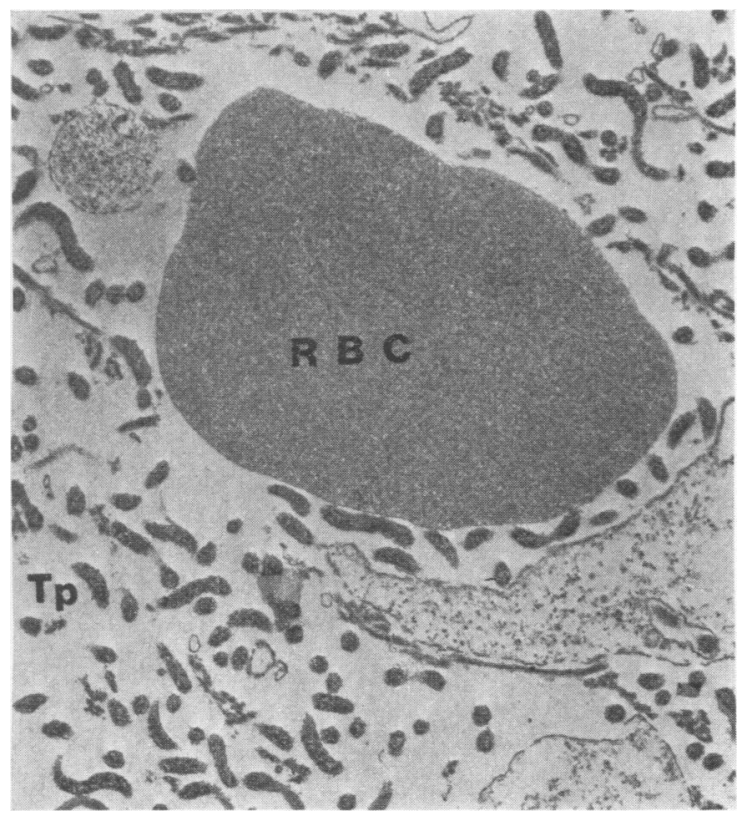

FIG. 2 Longitudinal and cross-sections of treponemes along with some tissue debris $(T D) \times 31,500$

FIG. 4 Thin cross-section and longitudinal sections of numerous treponemes $(T p)$ surrounding a red blood cell $(R B C) \times 13,700$

(1) In the oxygen environment the organisms died.

(2) There is evidence that other anaerobic organisms survive in oxygen without utilizing it (Loesche, 1969).

Since there is a reasonable doubt that the oxygen
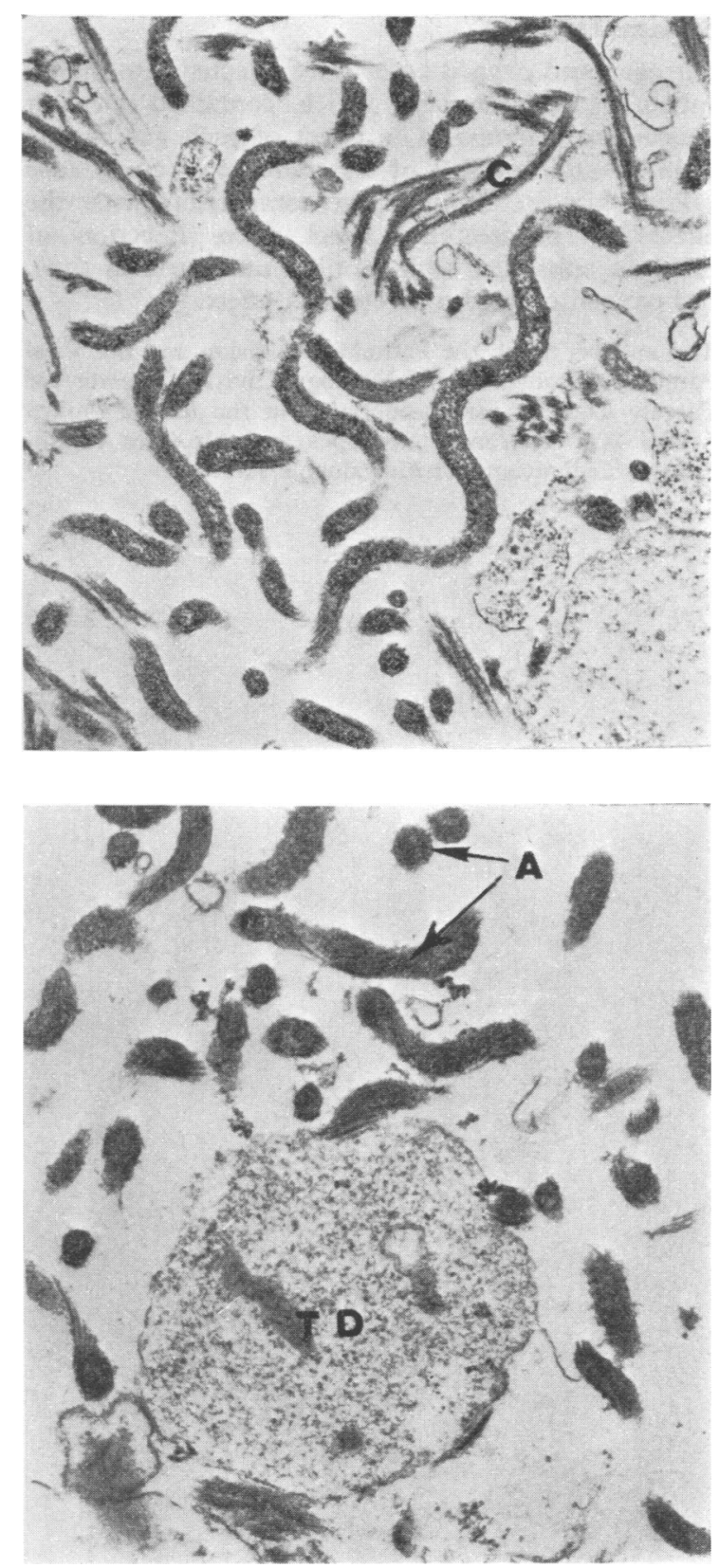

FIG. 3 Thin section of treponemes among collagen fibres $(C)$ in testicular suspension $\times 17,230$

FIG. 5 Thin cross-section and longitudinal section, showing axial filaments $(A)$ of T. pallidum along with tissue debris $(T D)$ in suspension $\times 26,800$

uptake by the $T p$ suspensions prepared by Cox and Barber (1974) was due entirely to $T p$, we suggest that additional research is needed to determine more fully the atmospheric requirements of $T p$. 


\section{Summary}

Nitrogen and oxygen gases were injected into mouse subcutaneous chambers which contained virulent Treponema pallidum. The effect of each gas on the viability and survival of $T$. pallidum in an in vivo system was determined. In comparison with the effects in nontreated control mice, injection of nitrogen enhanced both motility and survival time, but oxygen exerted a deleterious effect.

The authors thank the Pathology Division and the Viral Pathology Branch of the Virology Division, Center for Disease Control, for co-operation in the use of Philips Model 200 electron microscopes and Mr. Lee Smith, Animal Technician, for his valuable service.

\section{References}

ARko, R. J. (1973) Laboratory Animal Sci., 23, 105

Cox, C. D., and BARBER, M. K. (1974) Infect. and Immun., 10, 123

KIRÁLY, K. (1952) Personal communication

LOESCHE, W. J. (1969) Appl. Microbiol., 18, 723

MoRgan, H. J., and VRYonis, G. P. (1938) Amer. F. Syph., 22, 462

Nelson, R. A., and Steinman, H. G. (1948) Proc. Soc. exp. Biol. (N.Y.), 68, 588

ReYNolds, E. S. (1963) f. Cell Biol., 17, 208

TURNER, T. B., and Hollander, D. H. (1957) 'Biology of the Treponematoses', WHO Geneva Monograph Series No. 35 